\title{
High frequency of visceral leishmaniasis in dogs under veterinary clinical care in an intense transmission area in the state of Tocantins, Brazil
}

\author{
Helcileia Dias Santos ${ }^{1 *}$ Samara Rocha Galvão ${ }^{1}$ Francisca Elda Ferreira Dias $^{1}$ \\ Taiã Mairon Peixoto Ribeiro ${ }^{1}$ Osmar Negreiros Filho ${ }^{2}$ \\ Sebastiana Adriana Pereira Sousa ${ }^{3}$ Silvia Minharro ${ }^{1}$
}

${ }^{1}$ Escola de Medicina Veterinária e Zootecnia, Universidade Federal do Tocantins (UFT), Campus Araguaína, BR 153, Km 112, 77804-970, Araguaína, TO, Brasil. E-mail: hdsantos@uft.edu.br. "Corresponding author.

${ }^{2}$ Secretaria Estadual de Saúde, Tocantins, TO, Brasil.

${ }^{3}$ Curso de Pós-graduação em Ciência Animal, Universidade Federal de Goiás (UFG), Goiânia, GO, Brasil.

\begin{abstract}
A direct search for parasites were used as the diagnostic test to determine the frequency of Leishmania spp. infection in dogs (Canis lupus familiaris) under veterinary clinical care in the city of Araguaina, Tocantins, Brazil. For this approach, lymph node cell samples were collected using needle aspiration from 649 dogs of different breeds and ages. Two hundred and sixty four (40.7\%) dogs tested positive for amastigote forms of Leishmania spp. Furthermore, 202 (76.5\%) dogs that tested positive showed some clinical sign of disease, while 62 (28.4\%) dogs were asymptomatic. Dogs $<2$ years old or those that lived alongside poultry species in peri-domicile areas had a greater chance of infection $(P<0.05)$. Our results revealed the importance of frequently monitoring leishmaniasis in dogs, and the need to train veterinary professionals who work in high-transmission areas on the clinical diagnosis of canine visceral leishmaniasis.

Key words: visceral leishmaniasis, cytodiagnosis, risk factors, prevention and control.
\end{abstract}

Alta frequência de Leishmaniose visceral em cães submetidos a atendimento clínico-veterinário em área de transmissão intensa no estado do Tocantins, Brasil

RESUMO: O objetivo deste estudo foi determinar a frequência de infecção por Leishmania spp. em cães (Canis lupus familiaris) da cidade de Araguaína, Tocantins, submetidos à atendimento clínico-veterinário, utilizando a pesquisa direta do parasito como forma de diagnóstico. A população estudada foi de 649 cães, de diferentes raças e idades, dos quais foi coletada uma amostra de células de linfonodo através de punção aspirativa. Entre os animais com exame positivo 202 (76,5\%) apresentaram algum sinal clínico da doença e 62 (28,4\%) animais animais assintomáticos apresentaram exames positivos. Animais com até dois anos de idade e que conviviam com galináceos no peridomicílio apresentaram maior chance de infecção $(P<0,05)$. Os resultados demonstram a necessidade de vigilância constante dos animais em relação a leishmaniose e denota a importância do aperfeiçoamento dos profissionais veterinários, que atuam em áreas de transmissão intensa, para o diagnóstico clínico da leishmaniose visceral canina.

Palavras-chaves: Leishmaniose visceral, citodiagnóstico, fatores de risco, prevenção e controle.

\section{INTRODUCTION}

Visceral leishmaniasis (LV) is a disease in the Americas that is caused by the protozoa Leishmania (Leishmania) infantum (Sin. L. (L.) chagasi). This disease affects domestic and wild animals, and humans. Dogs (Canis lupus familiaris) are considered to be the main domestic reservoir. The main vector, Lutzomyia longipalpis, and more rarely, $L$. cruzi, feed on dogs and subsequently transmit the disease to humans (DANTAS TORRES et al., 2009). A disease incidence rate is an estimate of the risk of developing a disease in an exposed population. A high incidence rate emphasizes the need to implement robust control measures. A highest incidence rate (34.98 per 100,000$)$ of VL has been reported in Tocantins, Brazil in 2011 (DATASUS, 2015). This State has been considered by the Pan American Health Organization as high transmission area (OPAS, 2014). Araguaína a city located in the extreme north of Tocantins - is a municipality with the highest number of reported cases. According to the Araguaína's Center for Zoonosis Control, 1,114 cases were reported between 2001 and 2013 .

Measures adopted in Brazil to control VL involve treating infected persons, controlling vectors, and diagnosing and removing in- 
fected dogs. Leishmania diagnosis in humans and animals should be based on observing the clinical signs and symptoms that are suggestive of the disease followed by a laboratory test that can confirm the presence of parasites in tissues, or the presence of anti-leishmania antibodies in serum (COURA-VITAL et al., 2011; BRASIL, 2014). Canine visceral leishmaniasis (CVL) has signs that are similar to other diseases, which is challenging for clinical diagnosis (BANETH, et al., 2008). Therefore, it is important that other methods complement diagnosis.

A parasitology examination that detects amastigote forms of Leishmania spp. is a direct method that can be used to diagnose CVL. Tissue fragments can be used from the spleen or liver, or the material from lymph node or bone marrow needle aspirations can be used (BABIKER et al., 2007). The sensitivity of this method depends on factors such as parasite density, type of material collected, and time for which the microscopic analysis was performed. Sensitivity may also differ depending on the organ under analysis. Nevertheless, a positive result confirms infection (BABIKER et al., 2007; BRASIL, 2014).

The present study aimed to determine the frequency of CVL in Araguaína, Tocantins, Brazil using a direct search for parasites as the diagnostic test; this study also assessed the individual factors and clinical characteristics that are associated with the occurrence of CVL.

\section{MATERIALS AND METHODS}

The present study was performed in the urban area of the Araguaína municipality located in north Tocantins, Brazil at $7^{\circ} 11^{\prime} 28^{\prime}$ " latitude, $48^{\circ} 12^{\prime} 26^{\prime \prime}$ longitude, with an average altitude of $277 \mathrm{~m}$. The municipality covers a $4,000-\mathrm{km}^{2}$ area, with a resident population in the urban area of 142,925 inhabitants (IBGE, 2010).

The samples analyzed were collected from 649 dogs under veterinary care at five Araguaína city clinics from 2007 to 2014. Lymph node needle aspirations were collected by the veterinarians at these clinics and sent to the Parasitology Laboratory of the School of Veterinary Medicine and Animal Science at the Universidade Federal do Tocantins for leishmaniasis diagnosis using a direct parasitic search. Samples were stained using the Rapid
Panoptic Staining Kit (Instant Prov, New Prov, Brazil), and the slides were analyzed within 20 minutes using an optical microscope with an immersion objective. Samples were considered positive when at least one complete amastigote form of Leishmania spp. (nucleus, kinetoplast, and cytoplasmic limit) was observed.

Dogs were classified as either asymptomatic (no signs suggestive of disease) or symptomatic (the presence of at least one sign of VL infection such as dermatologic and ophthalmic disorders, lymphadenomegaly, splenomegaly, onychogryphosis, apathy, or severe loss of weight) (COURA-VITAL et al., 2011; ALMEIDA et al., 2013). Additional data such as sex, age, breed, presence of other animals in the domicile (dogs, cats and poultry), access to the outdoors (either free or controlled), permanent site of the animal defined by a period of 18 to 22 hours (inside or outside the domicile), and presence or absence of organic matter in the peri-domicile were voluntarily provided by the owners. This data was registered by the veterinarian in a standardized form provided by the laboratory for monitoring the samples. The data were tabulated and descriptive analysis was performed using Epi Info 3.5.4. A chi-square test with Yates correction was calculated with a $95 \%$ confidence interval.

\section{RESULTS AND DISCUSSION}

Amastigote forms of Leishmania spp. were observed in 264 (40.7\%) samples (Table 1). The prevalence of Leishmania in our sample population was greater than that observed in other studies where the same technique was used (ALMEIDA et al., 2010), and similar to the results observed in seroprevalence studies performed in other areas of Brazil where the infection is endemic (AMÓRA et al., 2006; FRAGA et al., 2012). In our study, the method used had a low sensitivity, which may indicate that the true prevalence may be detected by using more sensitive diagnostic methods (GOMES et al., 2008; SRIVASTAVA et al., 2011).

Our analysis showed that sex was not a risk factor for CVL $(\mathrm{P}=0.278)$, which was also observed in other studies in Brazil (AMÓRA et al., 2006; ALMEIDA et al., 2010; SILVA et al., 2010; FIGUEIREDO et al., 2014). However, a higher CVL frequency has been reported in male dogs (DANTAS-TORRES et al., 2006; JULIÃO et al., 
Table 1 - Result of direct parasitological exam through needle aspiration of lymph node cells for screening Leishmania spp. in dogs from the urban area at the municipality of Araguaína - TO.

\begin{tabular}{lccc}
\hline Result & Frequency & Percentage & - \\
\hline Negative & 385 & $59.3 \%$ & $54.4 \%-63.1 \%$ \\
Positive & 264 & $40.7 \%$ & $36.9 \%-44.6 \%$ \\
Total & 649 & $100.0 \%$ & \\
\hline
\end{tabular}

2007). The CVL frequency was significantly greater in dogs $<2$ years old $(\mathrm{P}=0.042)$, which differed from the observations of BARBOSA et al. (2010), but similar to the results of DANTAS-TORRES et al. (2006) and FIGUEIREDO et al. (2014). The higher frequency in young dogs may be related to a lower immune maturity of these animals, whereas the adaptive immune system is not fully mature at birth. Only after weeks to months do most mammals become immunologically mature, which predisposes young animals to an increased risk of developing some diseases (DAY, 2007).

When stratified by smaller age bands ( $<1$ year, 1-6 years, and $>6$ years $)$, we observed a significantly lower CVL frequency $(\mathrm{P}=0.002)$ in $\operatorname{dogs}>6$ years $(23.5 \%)$. No difference was observed for the remaining groups $(46.7 \%,<1$ year; $43.3 \%, 1-6$ years). These findings differed from the results observed in other areas of Brazil where the infection is endemic, where the frequency of leishmaniasis was higher in dogs that were 1-6 years old (RONDON et al., 2008). These results suggest that in areas of high incidence, the Leishmaniasis infection risk may be related to environmental rather than individual factors of the host, as also suggested by ALMEIDA et al. (2010).

We did not observe any significant differences with regard to a dog belonging to a specific breed or not (39.3\% and $41.8 \%$, respectively). This lack of significance may be explained by the diversity of the breeds examined, considering that there is evidence of differences in genetic susceptibility between some breeds (BANETH et al., 2008). Among the dogs with a specific breed, the frequency of Leishmania spp. was greater in dogs belonging to the Boxer (62.5\%), Dachshund (47.1\%), and Rottweiler $(45.2 \%)$ breeds. Similar observations were reported by other studies that showed that the Leishmania frequency was higher in dogs with shorter hair and larger bodies (MOREIRA Jr. et al., 2003; JULIÃO et al., 2007; RONDON et al., 2008).

The presence of other animals in the domicile, such as other dogs and cats, were not positively associated with CVL. However, in houses where the owner reported the presence of poultry in the peri-domicile area, a significant increase in CVL (OR 2.31; $\mathrm{P}=0.042$ ) was observed. The presence of poultry as a risk factor for CVL has also been observed by MOREIRA Jr et al. (2003) and OLIVEIRA et al. (2010). These studies reported that this association may occur because chicken blood may provide food for the vector or that the organic matter produced may favor vector development. However, it should be noted that in other studies conducted in Brazil, the presence of poultry near dogs could offer protection against CVL (AZEVEDO et al., 2008; BELO et al., 2013). Therefore, this variable should be further studied to gain insight on its role in the epidemiology of CVL.

In $90 \%$ of 427 dogs, the owners reported that the dogs had restricted access to the outdoors. This variable did not show any association with CVL, which is in agreement with the observations of MOREIRA JR. et al. (2003) and COURAVITAL et al. (2011). These results indicated that animal infection may have occurred within the domicile. Furthermore, no significant association was observed between CVL and the presence of organic matter in the peri-domicile area (leaves and rubbish) or the permanent site of the animal defined by the consecutive period of stay from 6 PM to 10 PM.

CVL clinical signs were observed in $76.5 \%$ of dogs that tested positive for amastigote forms of Leishmania spp. while $28.4 \%$ of dogs were asymptomatic (Table 2). This finding is in agreement with the findings of ALMEIDA et al. (2010) and FIGUEIREDO 
Table 2 - Variables related to the individual characteristics and permanent site of dogs in the city of Araguaína that are associated with positivity for Leishmania spp. in needle aspirations of lymph node cells.

\begin{tabular}{|c|c|c|c|c|c|}
\hline Variable & $\mathrm{N}$ & $+(\%)$ & OR & CI $(95 \%)$ & $\mathrm{P}$ \\
\hline \multicolumn{6}{|l|}{ Sex } \\
\hline Male & 314 & $135(43.0)$ & 1.206 & $0.880-1.651$ & 0.278 \\
\hline Female & 330 & $127(38.5)$ & & & \\
\hline \multicolumn{6}{|l|}{ Age } \\
\hline Up to 2 years & 285 & $133(46.7)$ & 1.468 & $1.028-2.101$ & 0.042 \\
\hline$>2$ years & 225 & $84(37.3)$ & & & \\
\hline \multicolumn{6}{|l|}{ Breed } \\
\hline Defined breed & 364 & $221(60.7)$ & 0.900 & $0.648-1.253$ & 0.591 \\
\hline Mongrel & 244 & $142(58.2)$ & & & \\
\hline \multicolumn{6}{|c|}{ Other animals in the domicile } \\
\hline Dog & 255 & $102(40.0)$ & 0.955 & $0.692-1.316$ & 0.841 \\
\hline Cat & 23 & $12(52.2)$ & 1.619 & $0.703-3.726$ & 0.253 \\
\hline Poultry & 30 & $18(60.0)$ & 2.317 & $1.086-4.944$ & 0.042 \\
\hline \multicolumn{6}{|c|}{ Access to the outdoors } \\
\hline Free & 39 & $16(41.0)$ & 1.012 & $0.518-1.977$ & 0.893 \\
\hline Controlled & 388 & $158(40.7)$ & & & \\
\hline \multicolumn{6}{|c|}{ Permanent site from 18 to 22 hours } \\
\hline Within the house & 365 & $153(41.9)$ & 1.407 & $0.789-2.508$ & 0.307 \\
\hline Outside the house & 59 & $20(33.9)$ & & & \\
\hline
\end{tabular}

et al. (2014), and in contrast with the findings of DANTAS-TORRES et al. (2006) and SILVA et al. (2010), who reported a higher parasite frequency in asymptomatic animals. The animals analyzed in this study were those under veterinary care, and this condition may have contributed to the observation of a high frequency of symptomatic animals.

Dermatosis $(32.6 \%)$, lymphadenomegaly (27.7\%), weight loss (22.7\%), apathy (12.5\%), splenomegaly $(8.7 \%)$, and onychogryphosis $(7.2 \%)$ were the most frequently observed clinical signs associated with CVL (Table 3). These signs were also the most frequently reported for CVL from other locations (RONDON et al., 2008; ALMEIDA et al., 2010). The other signs observed were eye disease $(3.8 \%)$, limb edema $(2.3 \%)$, diarrhea $(1.5 \%)$, motor incoordination $(1.1 \%)$, hepatomegaly $(0.8 \%)$, and epistaxis $(0.4 \%)$.

The observations from this study indicated that in areas with a high prevalence of Leishmania spp., owners should monitor their dogs for CVL frequently. When a veterinarian detects a sign that is suggestive of CVL, they should perform complementary exams to confirm infection. The parasitology exam, despite having a low sensitivity, is low-cost, easy, and quick to perform in the veterinary practice. The exam may also help with the early implementation of control measures for the domestic reservoir, thereby reducing human risk of infection.

\section{CONCLUSION}

The results reported in our study indicated that there is a high CVL frequency in Araguaína, Tocantins. Animals $<2$ years old and living alongside poultry in the peri-domicile areas are at the greatest risk of infection. Dermatosis was the most frequently observed clinical sign. In high-incidence areas, diagnosis through testing of samples of lymph node needle aspirations for parasites may be a faster and safer method to monitor dogs. However, this diagnostic approach does not exclude the importance of using serological or molecular methods for the diagnosis of visceral leishmaniasis, especially in asymptomatic dogs that have negative results from a direct examination. Therefore, it is important to train veterinarians in the clinical and laboratory diagnosis of CVL. 
Table 3 - Variables related to the clinical characteristics of the dogs from the city of Araguaína that are associated with positivity for Leishmania spp. in needle aspirations of lymph node cells.

\begin{tabular}{|c|c|c|c|c|c|}
\hline Variable & $\mathrm{N}$ & $+(\%)$ & OR & CI $(95 \%)$ & $\mathrm{P}$ \\
\hline \multicolumn{6}{|l|}{ Clinical signs } \\
\hline Symptomatic & 431 & $202(46.9)$ & 2.22 & $1.564-3.149$ & 0.000 \\
\hline Asymptomatic & 218 & $62(28,4)$ & & & \\
\hline \multicolumn{6}{|l|}{ Apathy } \\
\hline Yes & 52 & $33(63.5)$ & 2.75 & $1.528-4.954$ & 0.0008 \\
\hline No & 597 & $231(38.7)$ & & & \\
\hline \multicolumn{6}{|c|}{ Lymphadenomegaly } \\
\hline Yes & 151 & $73(48.3)$ & 1.51 & $1.042-2.171$ & 0.036 \\
\hline No & 498 & $191(38.4)$ & & & \\
\hline \multicolumn{6}{|l|}{ Skin lesion } \\
\hline Yes & 144 & $86(59.7)$ & 2.72 & $1.863-3.982$ & 0.000 \\
\hline No & 505 & $178(35.2)$ & & & \\
\hline \multicolumn{6}{|l|}{ Weight loss } \\
\hline Yes & 103 & $60(58.3)$ & 2.34 & $1.524-3.590$ & 0.000 \\
\hline No & 546 & $204(37.4)$ & & & \\
\hline \multicolumn{6}{|l|}{ Splenomegaly } \\
\hline Yes & 35 & $23(65.7)$ & 2.97 & $1.449-6.073$ & 0.003 \\
\hline No & 614 & $241(39.3)$ & & & \\
\hline \multicolumn{6}{|c|}{ Onychogryphosis } \\
\hline Yes & 32 & $19(59.4)$ & 2.22 & $1.076-4.576$ & 0.043 \\
\hline No & 617 & $245(39.7)$ & & & \\
\hline
\end{tabular}

\section{ACKNOWLEDGEMENTS}

We thank the Brazilian Conselho Nacional de Desenvolvimento Científico e Tecnológico (CNPq) and the Departamento de Ciência e Tecnologia do Estado de Tocantins for supporting our research and Universidade Federal do Tocantins (UFT)/Pró-Reitoria de Pesquisa e Pós-graduação (Propesq) for the research grant.

\section{BIOETHICS AND BIOSSECURITY COMMITTEE APPROVAL}

This study was approved by the Research Ethics Committee of the Fundação de Medicina Tropical do Tocantins, under number $32 / 2010$.

\section{REFERENCES}

AMÓRA, S. S. A. et al. Factors related to positive testing of dogs for visceral leishmaniasis in endemic area in the state of Rio Grande do Norte, Brazil. Ciência Rural, v.36, n.6, p.1854-1859, 2006. Available from: <http://www.scielo.br/pdf/cr/v36n6/a29v36n6.pdf>. Accessed: Mar. 03, 2016. doi: 10.1590/S0103-84782006000600029.

ALMEIDA, A. B. P. F. et al. Prevalência e epidemiologia da leishmaniose visceral em cães e humanos, na cidade de Cuiabá, Mato Grosso, Brasil. Ciência Rural, v.40, n.7, p.1610-1615, 2010. Available from: <http://www.scielo.br/pdf/cr/v40n7/a637cr2726.pdf>. Accessed: Mar. 06, 2016. doi: 10.1590/S0103-84782010005000102.
ALMEIDA, A. B. P. F. et al. Canine visceral leishmaniasis: diagnostic approaches based on polymerase chain reaction employing different biological samples. Diagnostic Microbiology and Infectious Disease, v.76, p.321-324, 2013. Available from: <http://dx.doi. org/10.1016/j.diagmicrobio.2013.03.017>. Accessed: Dec. 20, 2013. doi: 10.1016/j.diagmicrobio.2013.03.017.

AZEVEDO M. A. A. et al. Avaliação da leishmaniose visceral canina em Poxoréo, Estado do Mato Grosso, Brasil. Revista Brasileira de Parasitologia Veterinária, v.17, n.3, p.123-127, 2008. Available from: <http://www.scielo.br/pdf/rbpv/v17n3/a01v17n3.pdf $>$. Accessed: Nov. 22, 2015. doi: 10.1590/S1984-29612008000300001.

BABIKER, Z. O. et al. Utility of lymph node aspiration in the diagnosis of visceral leishmaniasis in Sudan. American Journal of Tropical Medicine and Hygiene, v.76, n.4, p.689-693, 2007. Available from: <http://www.ajtmh.org/content/76/4/689.long > Accessed: Mar. 04, 2016.

BANETH, G. et al. Canine leishmaniosis - new concepts and insights on an expanding zoonosis: part one. Trends in Parasitology, v.24, n.7, p.324-330, 2008. Available from: $<$ http://www.sciencedirect.com/ science/article/pii/S1471492208001323>. Accessed: Aug. 07, 2016. doi:10.1016/j.pt.2008.04.001.

BARBOSA, D. S. et al. Seroprevalence and associated epidemiologic variables with canine visceral leishmaniasis in endemic area, são luis, Maranhão state, Brazil. Ciência Animal Brasileira, v.11, n.3, p.653-659, 2010. Available from: $<$ http://www.producao.usp. br/handle/BDPI/43966>. Accessed: Mar. 08, 2016. doi: 10.5216/ cab.v11i3.5933. 
BELO, V. S. et al. A systematic review and meta-analysis of the factors associated with Leishmania infantum infection in dogs in Brazil. Veterinary Parasitology, v.195, n.1-2, p.1-13, 2013. Available from: $<$ http:// www.sciencedirect.com/science/article/pii/S0304401713001556>. Accessed: Mar. 08, 2016. doi: 10.1016/j.vetpar.2013.03.010.

BRASIL. Ministério da Saúde. Secretaria de Vigilância em Saúde. Guia de vigilância em saúde. Brasília: Ministério da Saúde, 2014. Available from: <http://portalsaude.saude.gov.br/images/pdf/2016/ janeiro/15/guia-vigilancia-saude-atualizado-05-02-15-LV.pdf $>$. Accessed: Mar. 08, 2016.

COURA-VITAL, W. et al. Prevalence and factors associated with Leishmania infantum infection of dogs from an urban area of Brazil as identified by molecular methods. PLoS Neglected Tropical Diseases, v.5, n.9, p.e1291, 2011. Available from: <http://journals. plos.org/plosntds/article?id=10.1371/journal.pntd.0001291>. Accessed: Sept. 19, 2013. doi: 10.1371/journal.pntd.0001291.

DATASUS. Ministério de Saúde. Secretaria Executiva. Leishmaniose Visceral - Casos confirmados notificados no sistema de informação de agravos de notificação - Sinan Net. Available from: $<$ http://www. datasus.gov.br>. Accessed: Mar. 03, 2015.

DANTAS-TORRES, F. et al. Seroepidemiological survey on canine leishmaniasis among dogs from an urban area of Brazil. Veterinary Parasitology, v.140, p.54-60, 2006. Available from: <http://www. sciencedirect.com/science/article/pii/S0304401706001956>. Accessed: Feb. 27, 2013. doi: 10.1016/j.vetpar.2006.03.008.

DANTAS-TORRES, F. Canine leishmaniosis in South America. Parasite \& Vector, v.2, (Supp.1), S1, p.1-8, 2009. Available from: $<$ http://www.parasitesandvectors.com/content/2/S1/S1>. Accessed: Feb. 08, 2016. doi: 10.1186/1756-3305-2-S1-S1.

DAY, M. J. Immune system development in the dog and cat. Journal of Comparative Pathology, v.137, suppl.1, p.S10-S15, 2007. Available from: $<$ http://dx.doi.org.ez6.periodicos.capes.gov.br/10.1016/j.jcpa.2007.04.005>. Accessed: Aug. 07, 2016. doi: 10.1016/j.jcpa.2007.04.005.

FRAGA, D. B. M. et al. Temporal distribution of positive results of tests for detecting Leishmania infection in stray dogs of an endemic area of visceral leishmaniasis in the Brazilian tropics: A 13 years survey and association with human disease. Veterinary Parasitology, v.190, n.3-4, p.591-594, 2012. Available from: $<$ http:// www.sciencedirect.com/science/article/pii/S0304401712003226>. Accessed: Mar. 05, 2016. doi: 10.1016/j.vetpar.2012.06.025.

FIGUEIREDO, M. J. F. M. et al. Risk factors and clinical classification associated with seropositivity for canine visceral leishmaniasis. Ciencia Animal Brasileira, v.15, n.1, p.102-106, 2014. Available from: <http://www.scielo.br/pdf/cab/v15n1/13.pdf >. Accessed: Mar. 05, 2016. doi: 10.5216/cab.v15i1.25097.
GOMES, Y. M. et al. Diagnosis of canine visceral leishmaniasis: biotechnological advances. Veterinary Journal, v.175, p.4552, 2008. Available from: <http://www-sciencedirect-com.ez6. periodicos.capes.gov.br/science/article/pii/S1090023306002358>. Accessed: Aug. 05, 2016. doi: 10.1016/j.tvj1.2006.10.019.

IBGE (INSTITUTO BRASILEIRO DE GEOGRAFIA E ESTATÍSTICA). IBGE-Cidades. Available from: <http://www. ibge.gov.br/cidadesat/topwindow.htm?1>. Accessed: Jan. 10, 2015.

JULIÃO, F. S. et al. Investigation of risk areas as complemental methodology for the control of canine visceral. Pesquisa Veterinária Brasileira, v.27, n.8, p.319-324, 2007. Available from: $<$ http://www.scielo.br/scielo.php?script=sci_arttext\&pid=S0100736X2007000800001>. Accessed: Mar. 04, 2016. doi: 10.1590/ S0100-736X2007000800001.

MOREIRA JR, E. D. et al. Peridomestic risk factors for canine leishmaniasis in urban dwellings: new findings from a prospective study in Brazil. American Journal of Tropical Medicine and Hygiene, v.69, n.4, p.393-397, 2003. Available from: <http://www. ajtmh.org/content/69/4/393.long>. Accessed: Mar. 02, 2008.

OLIVEIRA, L. C. P. et al. Seroprevalence and risk factors for canine visceral leishmaniasis in the endemic area of Dias D'Avila, State of Bahia, Brazil. Revista da Sociedade Brasileira de Medicina Tropical, v.43, n.4, p.400-404, 2010. Available from: <http://dx.doi. org/10.1590/S0037-86822010000400013>. Accessed: Mar. 08, 2016. doi: $10.1590 / \mathrm{S} 0037-86822010000400013$.

OPAS (ORGANIZACION PANAMERICANA DE LA SALUD). Leishmaniasis. Epidemiological Report of the Americas, n.2, June 2014. Available from: <http://www.paho.org/hq/index. php?option $=$ com_topics\&view $=$ readall $\&$ cid $=6721 \&$ Itemid $=4075$ 4\&lang=pt $>$. Accessed: Mar. 05, 2016.

RONDON, F. C. et al. Cross-sectional serological study of canine Leishmania infection in Fortaleza, Ceará state, Brazil. Veterinary Parasitology, v.155, n.1-2, p.24-31, 2008. Available from: <http:// www.sciencedirect.com/science/article/pii/S0304401708002379>. Accessed: Mar. 08, 2016. doi: 10.1016/j.vetpar.2008.04.014.

SILVA, F. T. S. et al. Clinical aspects of canine visceral leishmaniasis in the district of Monte Gordo, Camaçari (BA). Revista Baiana de Saúde Pública, v.34, n.4, p.783-795, 2010. Available from: $<$ http://inseer.ibict.br/rbsp/index.php/rbsp/article/viewFile/71/78>. Accessed: Mar. 06, 2016.

SRIVASTAVA, P. etal. Diagnosis of visceral leishmaniasis. Transactions of the Royal Society of Tropical Medicine and Hygiene, v.105, n.1, p.1-6, 2011. Available from: <http://trstmh.oxfordjournals.org.ez6. periodicos.capes.gov.br/content/105/1/1.full.pdf + html $>$. Accessed: Aug. 05, 2016. doi: 10.1016/j.trstmh.2010.09.006. 